DOI: 10.35784/IAPGOS.236

\title{
ASSESSMENT OF THE DIAGNOSTIC VALUE OF THE METHOD OF COMPUTER OLFACTOMETRY
}

\author{
Oleg Avrunin ${ }^{1}$, Yana Nosova ${ }^{1}$, Sergii Zlepko ${ }^{2}$, Ibrahim Younouss Abdelhamid ${ }^{1}$, Nataliia Shushliapina ${ }^{3}$ \\ ${ }^{1}$ Kharkiv National University of Radio Electronics, Kharkiv, Ukraine, ${ }^{2}$ Vinnytsia national Technical University, Vinnytsia, Ukraine, \\ ${ }^{3}$ Kharkiv National Medical University, Kharkiv, Ukraine
}

\begin{abstract}
Olfactory studies can be a criterion for evaluating rhinosurgical intervention, and olfactory impairment may indicate respiratory impairment. Therefore, the urgent task is to develop an integrated approach to determining respiratory and olfactory disorders. A structural scheme was developed for the method of objective diagnosis of respiratory and olfactory disorders, taking into account the measu, rement of both the aerodynamic parameters of nasal breathing and the calculation of energy characteristics, which are used to determine olfactory sensitivity. The diagnostic significance of the proposed method of analyzing rhinofolipometry data with regard to additional parameters was assessed - it is necessary to take into account the time and power of breathing when the threshold of sensation of the odorivector is at the transition point of the airflow mode to the turbulent quadratic. It has been established that it is advisable to use the energy criteria of nasal breathing, pneumatic power and energy of nasal breathing under the action of the corresponding odor vector for the assessment of respiratory impaired olfactory. To assess the respiratory impairment of olfactory, it is necessary to use the method in which an odor vector is installed in the air path of the rhinomanometer, and the patient is asked to perform breathing maneuvers with a consistent increase in respiration rate while fixing the time at which olfactory sensitivity is achieved and then determining the respiratory energy characteristics. A statistical processing of diagnostic results was carried out, which confirms the adequacy of the model of independent statistical verification and makes it possible to use this method for the functional diagnosis of respiratory-olfactory disorders and testing of respiratory-olfactory sensitivity. The probability index of the error of the second kind is 0.17 .
\end{abstract}

Keywords: odorector, olfakometry, rhinomanometery, nasal breathing

\section{OCENA WARTOSCI DIAGNOSTYCZNEJ METODY OLFAKTOMETRII KOMPUTEROWEJ}

\begin{abstract}
Streszczenie. Badania węchowe moga być kryterium oceny interwencji chirurgicznej nosa, a zaburzenia węchu moga wskazywać na zaburzenia oddychania. Dlatego też pilnym zadaniem jest opracowanie zintegrowanego podejścia do określania zaburzeń oddechowych $i$ węchowych. Opracowano schemat strukturalny dla metody obiektywnej diagnostyki zaburzeń oddechowych $i$ węchowych, uwzględniajacy zarówno pomiar parametrów aerodynamicznych oddychania nosowego, jak i obliczenie charakterystyki energetycznej, które sq wykorzystywane do określenia wrażliwości węchowej. Oceniono znaczenie diagnostyczne proponowanej metody analizy danych rhinofolipometrycznych w odniesieniu do dodatkowych parametrów - konieczne jest uwzględnienie czasu i mocy oddychania, gdy próg czucia zapachu znajduje się w punkcie przejściowym przeptywu powietrza do trybu turbulentnego. Ustalono, że wskazane jest stosowanie kryteriów energetycznych oddychania nosowego, sity pneumatycznej i energii oddychania nosowego pod wpływem odpowiedniego wektora zapachu do oceny zaburzeń oddechowych. W celu oceny zaburzeń oddychania wechu konieczne jest zastosowanie metody, w której wektor zapachu jest zainstalowany w przewodzie powietrznym rhinomanometru, a pacjent jest proszony o wykonywanie czynności oddechowych ze stałym zwiększeniem częstości oddychania przy jednoczesnym ustaleniu czasu, w którym osiagana jest wrażliwość węchowa, a następnie określenie charakterystyki energetycznej oddechu. Przeprowadzono statystyczna obróbkę wyników diagnostycznych, która potwierdza adekwatność modelu niezależnej weryfikacji statystycznej $i$ umożliwia wykorzystanie tej metody do diagnostyki funkcjonalnej zaburzeń oddechowo-zapachowych i badania wrażliwości oddechowo-zapachowej. Wskaźnik prawdopodobieństwa błędu drugiego rodzaju wynosi 0,17.
\end{abstract}

Slowa kluczowe: odorivector, olfaktometria, rhinomanometria, oddychanie przez nos

\section{Introduction}

Formulation of the problem. The problem of identifying respiratory-olfactory disorders is very complicated in modern otorhinolaryngology, because it requires a comprehensive approach [7, 8]. Objective dysfunction of varying degrees is observed in acute, allergic, vasomotor rhinitis, sinusitis, adenoiditis, nasal polyps, tumors of the nose and paranasal sinuses, infectious granulomas and other diseases. Almost all diseases of the nasal cavity, which occur with obstruction of its lumen, preventing the inflow of air and odors from the olfactory epithelium, suffers from an olfactory function that promotes the launch of various behavioral reactions.To identify smell disturbances, methods based on the subjective evaluation of the subjects (Sniffin' Sticks test, University of Pennsylvania Smell Identification Test, Tastepulvertest Olfactory Display using Pulse Ejection, Hand held smell test and others) are used to a greater extent [9]. The most common and objective instrumental method for the study of respiratory disturbances is the method of quantitative assessment of nasal breathing function rhinomatometry. This method is based on measuring the difference in pressure between the entrance and exit of the nasal cavity and the passage of air passing through this [24]. It should be taken into account that the disturbance of smell is closely related to the respiratory system. An olfactory study may be a criterion for evaluating rhinoconstrictive intervention, and a violation of the sense of smell may indicate respiratory disturbances. Therefore, the task of developing a comprehensive approach to the identification of respiratory and olfactory disorders is urgent.

\section{Analysis of recent research and publications}

When conducting anterior active rhinomatometry (AAR), the air flow rate $\mathrm{Q}$ is measured through one of the nasal passages and the pressure difference $\Delta p$ between the atmospheric and in the nasopharynx at the entrance to one of the nasal passages geometrically arranged with a differential sensor, and the breathing is carried out through another nasal passage. The reliability of the diagnosis thus significantly decreases due to the expansion of one nasal course in the tuning of another, and, consequently, the impossibility of the correct algebraic addition of successively measured air flow $Q_{L_{A A R}}$ and $Q_{R_{A A R}}$ through the left and right nasal passages respectively [5].

Active posterior rhinomanometry (APR) involves measuring the total airflow $\mathrm{Q}$ when breathing through the nose through both the nasal passages and the pressure drop $\Delta p$ between the atmospheric and in the nasopharynx (the distal end of the measuring tube of the pressure sensor is introduced through the oral cavity) (Fig. 1).

Since the analysis of recent researches and publications has shown that the method of rhinomatometry is the most objective functional method of modern otorhinolaryngology diagnosis, and the method of dynamic active posterior rhinomanometry (APR) is more reliable than the anterior active rhinomatometry, then it is proposed to add a definition to the standard APR method some parameters related to the function of the smell $[16,23]$. 


\section{The aim of the study}

The aim of the study is to develop a method for analyzing rinolefactometry data for functional diagnosis of respiratoryolfactory disturbances and to evaluate the diagnostic significance of the proposed method.

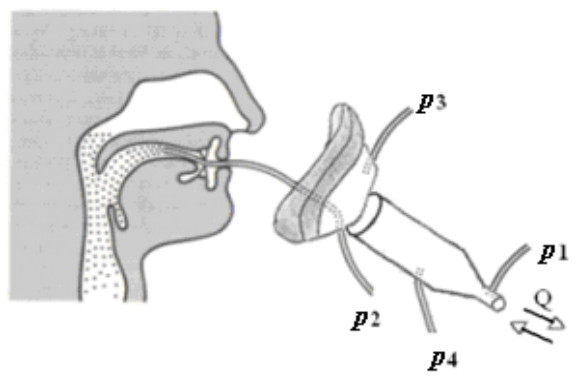

a)

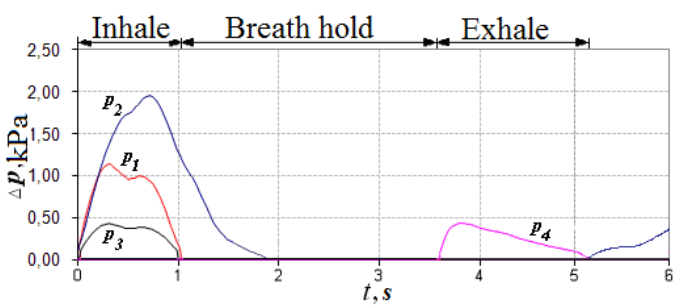

b)

Fig. 1. Location of measuring transducers in the device TNDA-PRH - a, and the corresponding diagram of the respiratory cycle $-b$ [9]

\section{Experimental}

Thus, a structural scheme of the method for the objective diagnosis of respiratory and olfactory disturbances was developed, taking into account the measurements of both aerodynamic indices of nasal breathing and the calculation of energy characteristics $[9$, $16,23]$, by which the olfactory sensitivity was determined (see Figure 2) $[5,6]$.

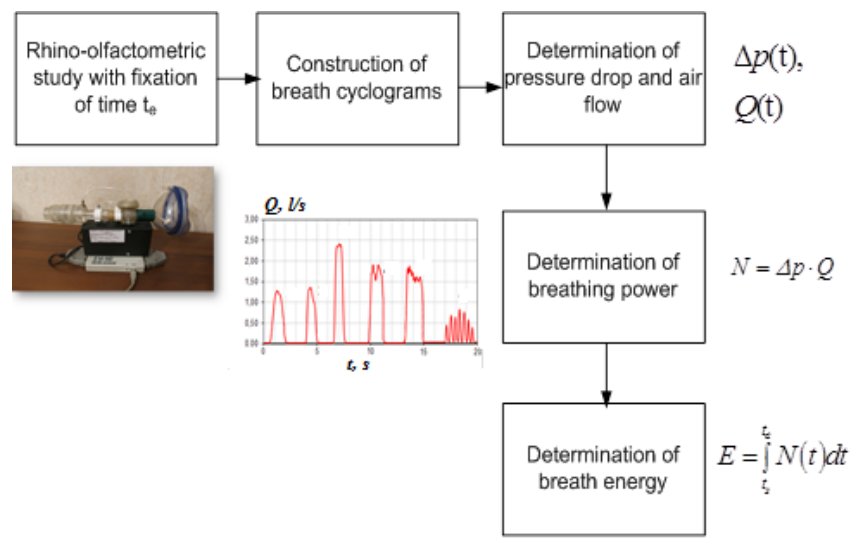

Fig. 2. Structural scheme of the method for the objective diagnosis of respiratory and olfactory disturbances

The computer olfactometry method for determining respiratory-olfactoral disorders in the first stage involves performing the preparation for a dynamic rhinomatometry (rinoflowmetry) procedure, in which measurements of pressure drop $\Delta \mathrm{p}$ on the nasal cavity and air flow rates $\mathrm{Q}$ in the nasal breath are measured.

A carrier of a single vector, for example, a hygroscopic cylindrical ring gasket, impregnated with a solution of a specific odorant, is placed in the airway of the rhinomanneter, usually at the inlet of the sensor for measuring the flow of air. As rhinomanometer it is possible to use a rinomanometer such as TNDA-PRH (KHNURE, Ukraine [3]), ATMOS 300 (ATMOS MEDIZINTECHNIK GMBH, Germany) or their analogues $[3,13]$.
For the study of olfactory sensitivity, three olfactory substances of varying receptor activity are used $[9,13]$ : a solution of valerianum at a concentration of $0.05 \%$ that is caused by the $n$ nerve. olfactorius, acetic acid $0.04 \%$, due to n. trigeminis and ammonia $0.004 \%$ due to $\mathrm{n}$. glossopharingeus.

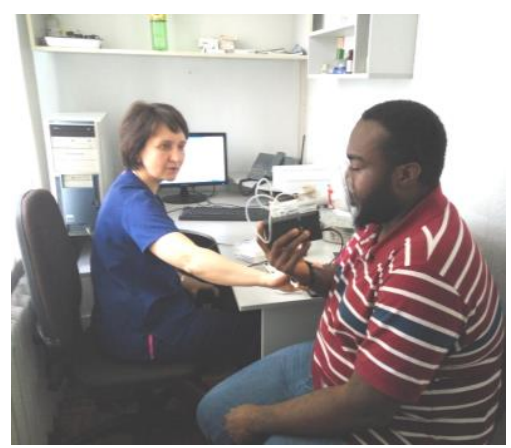

Fig. 3. Study of olfactory sensitivity

Next, the procedure of dynamic rinoflowometry is directly performed with the aid of a rhinomanneter for obtaining respiration cyclones, representing the dependences of the flow of $\mathrm{Q}(\mathrm{t})$ and the pressure drop $\Delta \mathrm{p}(\mathrm{t})$ on the nasal cavity from time. Graphic materials presented in Figure 2 are illustrations of the computer rhinomanometer TNDA-PRH with an olfactometric nozzle [6] (certificate of metrological attestation No 05-0102 dated 01.04.2010) [17, 26].

At the same time, the patient performs respiratory maneuvers with an increase in their intensity and the time of the appearance of olfactory sensitivity is recorded automatically. Next, the calculation of the pneumatic power $N(t)$ cyclogram breathing according to the formula (1):

$$
N(t)=\Delta p(t) \cdot Q(t) .
$$

Determination of energy E respiration, which characterizes the calorimetric costs of breathing in the emergence of sensitivity to the odorivector, is carried out by integrating the cyclogram of the pneumatic power of breathing by the formula (2):

$$
E=\int_{t_{s}}^{t_{e}} N(t) d t
$$

where $t_{s}-$ is the starting time of the study, as a rule, is taken equal to $0 ; t_{e}-$ is the time when the odor vector sensitivity appears.

Integration is performed numerically by the trapezoid method.

Experimental way on the basis of conducted research was developed the classification of the degree of violation of perception of odors (Fig. 3):

$\mathrm{E} \leq 2 \mathrm{~J}$ - conventionally normal sense of smell;

$2<\mathrm{E} \leq 8 \mathrm{~J}$ - average degree of dysosmia;

$8<\mathrm{E} \leq 16 \mathrm{~J}-$ severe degree of dysosmia;

E> $16 \mathrm{~J}$ - practically complete dysosmia.

The obtained results of the evaluation of the degree of violation of olfactory human function were confirmed by additional laboratory and clinical studies conducted by experts in the otorhinolaryngology department of the Kharkiv Regional Clinical Hospital [23, 24, 29].

\section{Results and discussion}

We will evaluate the diagnostic significance of the proposed method for analyzing rhinoolfactometry data taking into account additional parameters - it is necessary to take into account the time and respiration power when the threshold of sensation of the odorivector of values $Q_{s}$ and $\Delta p_{s} \equiv p_{s}$ characterizing the transition point of the air flow regime to the turbulent quadratic one. Let's consider a model of linear discrimination for the two states of the object $\left(\Theta_{0}-\right.$ conditional norm $\Theta_{1}-$ the state of breath-olfactory disturbances). The normalized Euclidean distance 
between controlled states and with the mutual independence of $n$ characteristics is calculated by the formula $(3)[12,28]$

$$
\delta=\sqrt{\sum_{i=1}^{n}\left(\frac{m_{i}^{(0)}-m_{i}^{(1)}}{\sigma_{i}}\right)^{2}}
$$

where $m_{i}^{(0)}, m_{i}^{(1)}$ - the mean values of the $\mathrm{i}$-th signs of the value of $X$ for the conditions $\Theta \in \Theta_{0}$ (conditional norm), and $\Theta \in \Theta_{1}$ (violation of the nasal breathing), respectively, $\sigma_{i}$ - mean-square deviations-signs that are determined according to the expression

$$
\sigma_{i}=\max \left(\sigma_{i}^{(0)}, \sigma_{i}^{(1)}\right) \text { where } \sigma^{(0)^{2}} \neq \sigma^{(1)^{2}}
$$

where $\sigma_{i}^{(0)}, \sigma_{i}^{(1)}$ - the mean square deviation is a sign for conditions (conditional norm), and (violation of nasal breathing).

In the normal distribution of values of the measured value, the probability of a second-order error when making decisions about the state of an object is determined through the integral of the Laplace $\Phi(\cdot)$ probability and is estimated by inequality (4) $[1,10]$

$$
P \leq 1-\Phi(\delta / 2)
$$

where $\delta$ is determined by the formula (3)

From formulas (3) and (4) it is obvious that the probability of the error is less, the more the dispersion square of the Euclidean distance is distributed between the vectors of the mean values of the signs $[20,22]$.

In the proposed method of computer olfakometry take into account the time and power of breath at the threshold of sensation of the odorivector are the following measured physical quantities (with the number of measured parameters $\mathrm{n}=5$ ):

$X_{1}$ - maximum air flow $Q$;

$X_{2}-$ pressure drop $\Delta p \equiv p$ at maximum air flow;

$X_{3}$ - air flow $Q_{s}$ in the presence of olfactory sensitivity;

$X_{4}$ - pressure drop $\Delta p_{s} \equiv p_{s}$ at appearance of olfactory sensitivity $[29,30]$;

$X_{5}$ - time $t_{s}$ of appearance of olfactory sensitivity.

The conditions of the conditional norm and the violation of the nasal breathing are designated, respectively, as $\Theta_{0}$ and $\Theta_{1}$. A total of 85 patients were examined, divided into two groups: 40 persons without nasal breathing and 45 persons with nasal breathing disorders. In this case, the maximum values of air flow $Q$ and pressure drop $\Delta p$ in the nasal cavity (the standard method of forced APR [5, 6, 29]) were determined, as well as during the computer olfactometry, the value of air flow $Q_{s}$ and pressure drop in the appearance of olfactory sensitivity in the presentation of the corresponding odorector. Then, for each group of patients, statistical indicators were calculated: the mean values and the mean square deviations of the corresponding measured values in the norm and in the respiratory-olfactory disturbances. The results of the calculation of the normalized Euclidean distance for the estimated indicators of the method are shown in Table 1 and displayed on the graph in Figure 4, a. Reducing the probability of a diagnostic solution error by adding the parameters studied to the model of discrimination is shown in Figure 4, b.

It is obvious that the addition of aerodynamic indices $Q_{S}, t_{s}$ and $\Delta p_{S}$ the point of transition to the turbulent quadratic air flow regime increases the normalized Euclidean distance in comparison with the standard method of forced APR by a value of 0.68 (1.4 times) and accordingly reduces the probability of a diagnostic error by a factor of 2 (from 0.35 to 0.17 ) [4, 11].

Moreover, it can be noted that the greatest contribution to reducing the probability of error is the air flow, as with standard forced rhinomanometry, and with olfactometry, as well as the time of the appearance of olfactory sensitivity to the odorivector. Pressure differences do not play a significant role in the pattern of discrimination $[2,14]$.
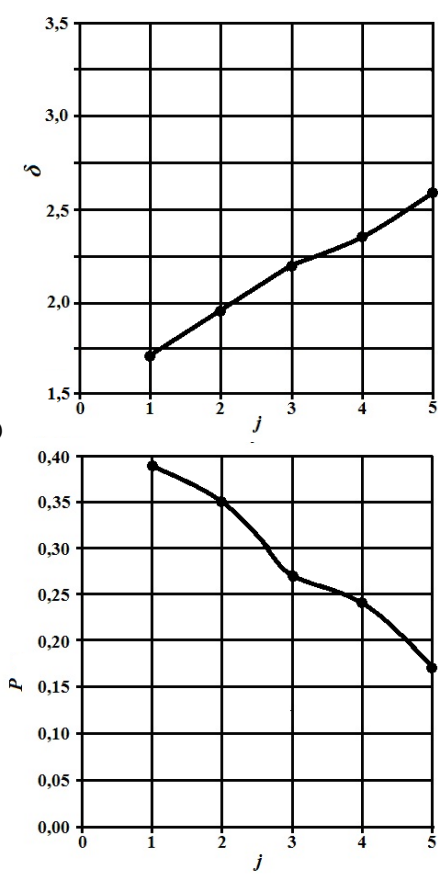

Fig. 4. Dependences of the increase of the normalized Euclidean distance (a) and the reduction of the probability of the decision error (b) as the signs are added to model 1 -for the air flow signal; 2 -for the differential pressure signal; 3 -air flow at the appearance of olfactory sensitivity, 4 - pressure drop in the appearance of olfactory sensitivity, 5 - the time of the appearance of olfactory sensitivity

Table 1. Results of discriminant analysis for the method of data analysis of computer olfaktometry with additional parameters taking into account the time and power of breath at the onset of the threshold of sensation of the odorivector [19,24, 30]

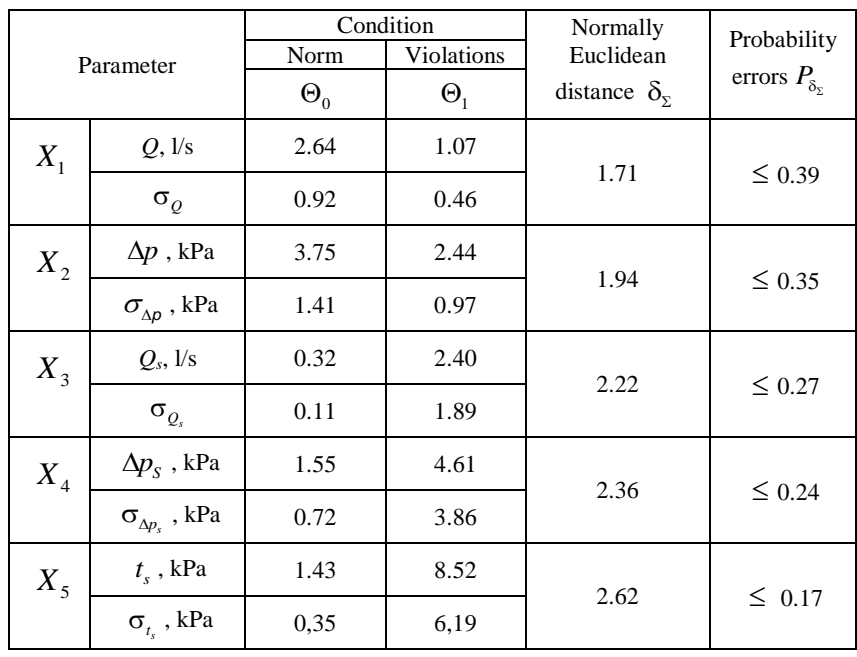

\section{Conclusions}

It is established that in assessing respiratory disturbances of the sense of smell it is expedient to use energy criteria of nasal breathing, pneumatic power and energy of nasal breath under the action of the corresponding odorivector. To assess respiratory disturbances of the sense of smell, it is necessary to use a method in which the odorivector is installed in the airway of the rhinomatometer and the patient is offered to perform respiratory maneuvers with a sequential increase in the intensity of respiration when fixing the time point at which smell sensitivity is achieved with the subsequent definition of the energy characteristics of respiration [25].

The statistical processing of the diagnostic results is confirmed, which confirms the adequacy of the model of independent statistical verification and makes it possible to use this method for functional diagnostics of respiratory-olfactory disturbances and testing of respiratory-olfactory sensitivity. The probability rate of the 2 nd kind of error is 0.17 . 


\section{References}

[1] Asakura K., Hayashi S.: Improvement of acquisition and analysis methods in multi-electrode array experiments with iPS cell-derived cardiomyocytes. Journal of Pharmacological and Toxicological Methods 75/2015, 17-26.

[2] Berul C.I., Aronovitz M.J., Wang P.J., Mendelsohn M.E.: In vivo cardiac electrophysiology studies in the mouse. Circulation 94/1996, 2641-2648.

[3] Chechel V., Vlasenko O., Rokunets I.: Patent No. 55671 UA, MPK A61B 5/04 Multichannel system for wireless transfer of action potentials in brain and spinal cord. National Pirogov Memorial Medical University 24/2010, 05836.

[4] Ciaccio E.J., Saltman A.E., Hernandez O.M., Bornholdt R.J., Coromilas J.: Multichannel data acquisition system for mapping the electrical activity of the heart. Pacing and clinical electrophysiology 28/2005, 826-838.

[5] Deacon M., Singleton D., Szalkai N., Pasieczny R., Peacock C., Price D., Boyd J., Boyd H., Steidl-Nichols J.V., Williams C.: Early evaluation of compound QT prolongation effects: a predictive 384-well fluorescence polarization binding assay for measuring hERG blockade. Journal of pharmacological and toxicological methods 55/2007, 255-264.

[6] Dutta S., Chang K.C., Beattie K.A, Sheng J., Tran P.N., Wu W.W., Wu M., Strauss D.G, Colatsky T., Li Z.: Optimization of an in silico cardiac cell mode for proarrhythmia risk assessment. Frontiers in Physiology 23/2017, 616.

[7] Food and Drug Administration, HHS. ICH: S7B nonclinical evaluation of the potential for delayed ventricular repolarization (QT interval prolongation) by human pharmaceuticals. Fed. Regist. 70/2005, 61133-4.

[8] Gintant G., Sager P.T., Stockbridge N.: Evolution of strategies to improve preclinical cardiac safety testing. Nature Reviews Drug Discovery 15/2016, $457-471$.

[9] Guth B.D.: Preclinical cardiovascular risk assessment in modern drug development. Toxicological Sciences 97/2007, 4-20.

[10] Henry P.D.: Comparative pharmacology of calcium antagonists: nifedipine, verapamil and diltiazem. The American journal of cardiology 46/1980, 1047-1058.

[11] Hofer E., Keplinger F., Thurner T., Wiener T., Sanchez-Quintana D., Climen V., Plank G.: A new floating sensor array to detect electric near fields of beating heart preparations. Biosensors and Bioelectronics 21/2006, 2232-2239.

[12] Kawakami K., Nagatomo T., Abe H., Kikuchi K., Takemasa H., Anson B.D. Delisle B.P., January C.T., Nakashima Y.: Comparison of HERG channe blocking effects of various $\beta$ blockers-implication for clinical strategy. British journal of pharmacology 147/2006, 642-652.

[13] Lee W., Windley M.J., Vandenberg J.I., Hill A.P.: In Vitro and in Silico Risk Assessment in Acquired Long QT Syndrome: The Devil Is in the Details. Frontiers in physiology $8 / 2017$.

[14] Malkin R.A., Pendley B.D.: Construction of a very high-density extracellula electrode array," American Journal of Physiology-Heart and Circulatory Physiology 279/2000, 437-442.

[15] Meyer T., Boven K.H., Günther E., Fejtl M.: Micro-electrode arrays in cardiac safety pharmacology. Drug Safety 27/2004, 763-772.

[16] Moroz V.M., Vlasenko O.V., Rokunets I.L., Chechel V.V., Yoltukhovskii M.V., Yankovskaya L.V.: Coupled Spike Activity in Micropopulations of Motor Cortex Neurons in Rats. Neurophysiology 42/2010, 110-117.

[17] Okada J.I., Yoshinaga T., Kurokawa J., Washio T., Furukawa T., Sawada K., Sugiura S., Hisada T.: Screening system for drug-induced arrhythmogenic risk combining a patch clamp and heart simulator. Science advances 4/2015, 140-142.

[18] Pavlov S.V., Barylo A.S., Kozlovska T.I., et al.: Analysis of microcirculatory disorders in inflammatory processes in the maxillofacial region on based of optoelectronic methods. Przegląd Elektrotechniczny 93(5)/2017, 114-117.

[19] Pavlov S.V., Kozhemiako V.P., Kolesnik P.F., et al.: Physical principles of biomedical optics: monograph. VNTU, Vinnytsya 2010.

[20] Pavlov S.V., Kozhemiako V.P., Petruk V.G., Kolesnik P.F. Photoplethysmohrafic technologies of the cardiovascular control. Universum, Vinnitsa 2007.

[21] Pavlov S.V., Kozlovska T.I., et al.: Calibration of the metrologica characteristics of photoplethysmographic multispectral device for diagnosis the peripheral blood circulation. Przegląd Elektrotechniczny 93(5)/2017, 79-82

[22] Pavlov S.V., Tuzhanskyy S.E., Kozlovska T.I., Kozak A.V.: A simulation model of distribution of optical radiation in biological tissues. Visnyk VNTU 3/2011, 191-195.

[23] Pradhapan P., Kuusela J., Viik J., Aalto-Setälä K., Hyttinen J.: Cardiomyocyte MEA data analysis (Cardio MDA) - a novel field potential data analysis software for pluripotent stem cell derived cardiomyocytes. PloS one 8/2013, 73637.

[24] Rampe D., Brown A.M.: A history of the role of the hERG channel in cardiac risk assessment. Journal of pharmacological and toxicological methods 68/2013, $13-22$.

[25] Serkova V.K., Pavlov S.V., et al.: Medical expert system for assessment of coronary heart disease destabilization based on the analysis of the level of soluble vascular adhesion molecules. Proc. SPIE 10445/2017, 104453 O.

[26] Singleton D.H., Boyd H., Steidl-Nichols J.V., Deacon M., de Groot M.J., Price D., Nettleton D.O., Wallace N.K., Troutman M.D., Williams C., Boyd J.G. Fluorescently labeled analogues of dofetilide as high-affinity fluorescence polarization ligands for the human ether-a-go-go-related gene (hERG) channel. Journal of medicinal chemistry 28/2007, 2931-2941.

[27] Stett A., Egert U., Guenther E., Hofmann F., Meyer T., Nisch W., Haemmerle H.: Biological application of microelectrode arrays in drug discovery and basic research. Analytical and bioanalytical chemistry 377/2003, 486-495.
[28] Valentin J.P., Hoffmann P., De Clerck F., Hammond T.G., Hondeghem L. Review of the predictive value of the Langendorff heart model (Screenit system) in assessing the proarrhythmic potential of drugs. Journal of pharmacological and toxicological methods 49/2004, 171-181

[29] Vandenberg J.I., Varghese A., Lu Y., Bursill J.A., Mahaut-Smith M.P., Huang C.L.: Temperature dependence of human ether-a-go-go-related gene $\mathrm{K}+$ currents. American Journal of Physiology-Cell Physiology 291/2006, 165-175.

[30] Vassilenko S., Valtchev, Teixeira J.P., Pavlov S.: Energy harvesting: an interesting topic for education programs in engineering specialities. Internet, Education, Science (IES-2016), 149-156.

[31] Wójcik W., Smolarz A.: Information Technology in Medical Diagnostics. LondonTaylor \& Francis Group CRC Press Reference, London 2017.

\section{Prof. Oleg Avrunin}

e-mail: oleh.avrunin@nure.ua

Doctor of Technical Sciences, professor, head of Biomedical Engineering Department, Kharkiv National University of Radio Electronics. Scientific supervisor of research work on research of theoretical and technical principles of diagnostics, assessment and correction of medical and social human conditions. Invited Professor in Gottfried Wilhelm Leibniz Universität Hannover (Germany) and Harbin Engineering University (China).

ORCID ID: 0000-0002-6312-687X

Ph.D. Yana Nosova
e-mail: yana.nosova@ nure.ua

Ph.D., Assistant of the Department of Biomedical Engineering, Kharkiv National University of Radio Electronics. As part of the team of authors of the patent "Device for the testing of respiratory disorders of smell" was awarded the diploma of the winner of the All-Ukrainian contest "Invention of the Year 2016 " in the nomination "Best invention in Kharkiv region". Research Interests: biomedical signal processing and images.

ORCID ID: 0000-0003-4310-5833

\section{Prof. Sergii Zlepko}

e-mail: szlepko@gmail.com

D.Sc., professor, Department of Biomedica Engineering, Vinnytsia National Technical University, Research Interests: biomedical signal processing and images, functional diagnostics

ORCID ID: 0000-0001-8849-4188
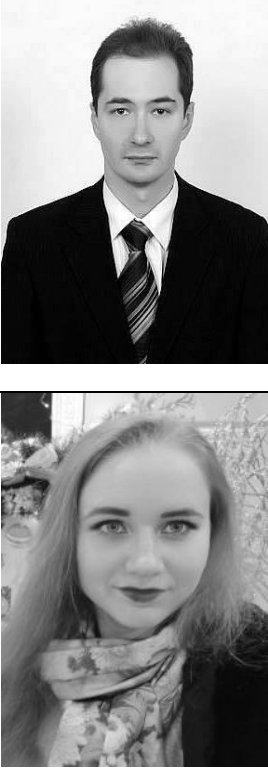

\section{M.Sc. Ibrahim Younouss Abdelhamid}

e-mail: ibrahim.younouss.abdelhamid@ nure.ua

Ph.D. Student, Department of Biomedical Engineering, Kharkiv National University of Radio Electronics. Research Interests: biomedical signal processing and images, functional diagnostics of nasa breathing.

ORCID ID: 0000-0003-2611-2417

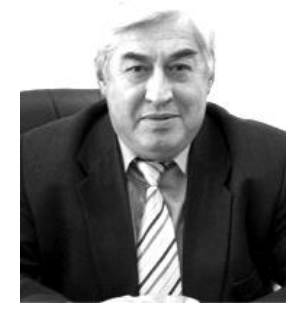

Ph.D. Nataliia Shushliapina

e-mail: schusha75@ukr.net

Ph.D., Associate Professor of department of Otolaryngology, Kharkiv National Medical University. Research Interests: diagnostics of respiratory-olfactory disorders, functional chronology, connection of microcirculation with chronic diseases of the nasal cavity, computer planning of rhinosurgical interventions, intellectual training systems in otorhinolaryngology.

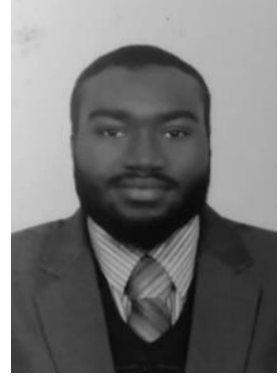

otrzymano/received: 30.05 .2019 przyjęto do druku/accepted: 15.06 .2019 